\title{
Research on Information Technology Application in Library and Information Service
}

\author{
Hui Wang \\ University Library, Jilin Agricultural University, 130118 Changchun, PR China
}

\begin{abstract}
Information technology becomes increasingly important for modern information services. This technology changes the traditional passive single service model of the traditional library and information, expands the collection volume of library and information institutions, and upgrades the information quality of library and information system staff. Besides, it also makes library and information service break through the time and space constraints, and speeds up the modernization process of library and information service. In China, various library and information service institutions should attach importance to the application of information technology, intensify the learning of information technology, change the management method of literature resources according to the development requirements of information technology, effectively improve service quality, and meet diversified needs.
\end{abstract}

Keywords-Information Technology; Library and Information Service; Application; Computer

\section{INTRODUCTION}

In modern society, information technology broadens the horizons of the readers, brings enormous changes to the daily life and reading demands of readers, and expands the reading volume of readers. However, it has also brought troubles to domestic universities, colleges, various library and information service staff and libraries. Therefore, the domestic library and information staff should actively introduce the advanced information technology, accelerate the learning of relevant business knowledge, and create a new booming situation.

\section{CURRENT APPLICATION OF INFORMATION TECHNOLOGY}

With microelectronics, multimedia, communications technology and databases as the main contents, the information technology has been increasingly widely applied to library and information service. The application of this technology is a microcosm of the rapid development of modern technology. The information technology accelerates the innovation of traditional library and information service.

\section{A. The Updating Speed of Computer Technology is accelerated}

The fifth-generation computer technology is being introduced. Soon this computer technology will also be applied to domestic computer library and information service. The computer hardware facilities are constantly updated from the lowest version of Pentium to the present highest version and from the core to dual-core configuration. This technology is updated at a fast pace, causing to accelerate the updating speed of computer technology in the library and information service.

\section{B. Extensive Application of Integrated Database Technology}

At present, the wireless network technology deepens and expands the information reading, sharing, collection, dissemination and processing conditions of readers. With the expansion of knowledge amount, the increase in library and information service quantity, the increase in the job variety and the increasingly high demands on database technology, in the traditional library and information service, the demands on database technology are not high. However, the reality requires various domestic library and information service institutions to realize the full coverage of wireless network technology, which is favorable for readers to achieve the information sharing function with ready tools. This is a landmark progress for library and information service. It will also have far-reaching impact and epoch-making significance to the human development. Therefore, a information technology revolution in the natural human form is triggered.

\section{IMPACTS OF INFORMATION TECHNOLOGY APPLICATION ON LIBRARY AND INFORMATION SERVICE}

\section{A. Information Collection}

In the past, when managing the library and information services, the library will produce lots of history information data every day. If the information and data are collected and analyzed by using traditional methods, it will take a long time, cause relatively strong emotional colors, and the structural analysis is not necessarily accurate. In library and information services, the application of information technology can effectively change this phenomenon, quickly and accurately combine with resource information, and exclude useless information. In such a way, it not only enriches the library resource information, but also greatly enhances the efficiency of library and information service.

\section{B. Optimization of Library Service}

The market development direction and network of library make it more difficult to cope with library information and the information becomes wider. In library and information service, to ensure the accurate 
information, it is essential to delete invalid information from massive information resources, and classify the information resources, so as to provide library staff with more convenient and effective information analysis for the information technology application, greatly reducing the work intensity and improve the work efficiency of the staff.

\section{Optimization of Library Information Resources}

Currently, many libraries are set as the digital library. Digital library refers to information resources sharing and digital information collection of resources. Under the impact of the Internet, the digital library contains a large number of invalid resources, so the information technology application will help library staff find useful information from those invalid resources, adopt the retrieval methods to quickly find those information resources, and greatly enhance the development and utilization of information resources.

\section{New Problems of Library and Information Service under the Network Environment}

In the network environment, information services have increasingly diverse information resources, and the network information has far exceeded the literature information. Under the network environment of information explosion, library and information service is facing a growing number of information data, greatly increasing the difficulty to find useful information. A sharp increase in network information not only eases people's information needs, but also increases the contradiction between network information and personalized information demands, which will increase the difficulty of library and information science services. In the past, for library and information services, the information needs were satisfied through the literature retrieval and services provided by information service institutions. With the development of network information technology, people may obtain the information network environment in different regions and different industries, so as to meet their personalized information needs. Nevertheless, some people are accustomed to the traditional information service mode, do not want to accept new ways of information services, and hinder the development of library and information service.

\section{E. Improve the information processing capability}

In the network environment, library information is obtained through wider and more complex means. In this case, the library information shall be more sensitive to analysis and judgment. Therefore, library and information talents should constantly enrich their cultural background and knowledge base, expand their horizons, judge the information in a faster and more accurate manner, obtain valuable information from massive information, in order to accommodate the development needs of library information.

\section{REFLECTION ON INFORMATION TECHNOLOGY APPLICATION IN LIBRARY AND INFORMATION SERVICE}

\section{A. Shortcomings of Information Technology}

In the library and information services, although information technology is irreplaceable and not omnipotent, in many cases, the information technology cannot replace other jobs. If the management is not in place, it cannot fully reflect the advantages of information technology. Information technology promotes development, making that the advantages of information technology cannot be fully reflected; information technology cannot substitute literature information, literature information is a symbol of library, digital library is used to substitute the literature information because it cannot attract wide readers. By analyzing the library information with the use of information technology, researchers can find the deficiencies, and optimize library and information service.

\section{INFORMATION PUSH TECHNOLOGY FEATURES IN LIBRARY AND INFORMATION SERVICE}

(1) Seamless connection. Seamless connection refers to a transparent computer room that can automatically establish a connection without user interaction or at least user interaction. In complex applications, the readers also complete an automatic connection over the intelligent access of current configuration, so that users may choose the connection method or set the connection priority, and effectively utilize broadband networks. It is more suitable for transmitting large amounts of data media.

(2) Personalized information service. Personalized information service is dynamic and active. Users can automatically track the user's request without requiring the user's requests, it needs to retrieve, process, and push information. Therefore, personalized active information service is one of its basic characteristics.

(3) User content customized services. Users can set the connection time and contents and choose the push information from the perspective of users, in order to meet the needs of different users.

(4) Effectively utilization of broadband. From the client perspective, broadband can be maximized by using data transmission in idle time. From the server side, according to the multiplexed forming principle, transfer data to the same minimum document with

\section{SIGNIFICANCE OF INFORMATION TECHNOLOGY ON MODERN INFORMATION SER VICE}

Stress that the information technology is completely separated in modern information, library and information services. Despite wide application of information technology, library and information service cannot be maintained. Modern library and information service is not merely a simple service access. It is essential to expand the service space of information technology, in order to meet the full range of readers. 


\section{A. Information Technology Makes Library and Information Service Staff Enhance Their Overall Quality}

Information technology improves the overall quality of library and information. Marx had pointed out the wide application in industrial revolution would cause machine exclusion of labor, inevitably leading to social unemployment rate. Employees who do not master this technology will be eliminated. Therefore, information technology is applied to promote library and information staff to improve service quality, strengthen business learning, and ultimately meet the technical needs of positions.

\section{B. Information Technology Expand the Amount of Library Resource Collections}

Information technology expands the number of technologies, accelerates the diffusion rate of knowledge, expands the variety and quantity of knowledge, and increase endless demand for knowledge of the reader. However, due to limitations of architectural space, it is difficult for resource collected from paper to meet the needs of all users. Information technology application is the solution to this problem, which can provide better, timelier and more accurate book information services for readers. As a result, various libraries and information institutions may focus on modern information technology collection, build and enhance the transfer of corresponding service capacity, strive to improve the infrastructure of modern information technology application, constantly increase the modern information technology service capabilities, along with the expanding service range of modern information technology.

\section{Information Technology Expand the Amount of Library Resource Collections}

Information technology expands the number of technologies, changes the applications of library and information technology and storage technology, collect the most completelmost detailed literature, communications technologies, and remote access to global data. In order to save manpower and material resources, the database technology ensures that information has a special database, allowing readers to search, query, copy, share and read. The computer technology facilitates the staff to update, manage and reduce labor intensity, improve work efficiency and make the library and information services break through time and space constraints.

\section{INFORMATION TECHNOLOGY APPLICATION STRATEGIES IN THE CHINESE LIBRARY AND INFORMATION INSTITUTIONS}

Information technology application in library and information service is a global trend as well as the industrial development trend. Chinese libraries and information institutions should pay attention to the application of this technology, improve the quality of related personnel, introduce some necessary technical facilities, and promote the digital information technology services

\section{A. Strengthen the skill training of personnel}

The successful library and information services are inseparable from attention of leaders and a lot of related personnel. Information technology has high requirements over the personnel. In addition to necessary expertise, the personnel shall also own skilled computer operating capacity, data processing capability and the abilities to copy information and communicate. However, it is hard to absorb a number of outstanding professionals, which may be realized by improving the overall quality of existing employees. In this case, the library and information institutions should intensify personnel training, improve staff skills, carry out multilevel, multi-type and multi-information service system, collect and process all kinds of information resources, do good works, and timely provide the latest guidance to users.

\section{B. Put emphasis on the collection and management of electronic literature data}

Collect and manage electronic documents. In China, library and information services are mainly concentrated on document procurement, collection and organization. However, with the rise of new readers, there are more and more information.

\section{Change the management method of literature resources according to information technology requirements}

At present, the paper file management in China is improved, yet the management of electronic documents is also blank. Library and information services with certain conditions are required, in order to explore and summarize the characteristics of electronic literature resources.

\section{TWO STAGES OF COMPUTER BOOK INFORMATION RETRIEVAL NETWORK}

The first stage of information retrieval network is the computer network. After 1973, due to the development of modern communications technology, the public transmission technology has been developed as science and technology information services. At this stage, for main information institution of each compute, each network node may be connected to multiple terminals. Each node is connected to communication lines, forming a network system. The crisscross information retrieval can overcome the area restrictions. Regardless of the distance of user search center, as long as there is a terminal information retrieval of stored document, any computer network will be found at any time, significantly promoting and expanding the information users to use electronic computers, increasing the information capacity, and improving the utilization efficiency of the computer. The second stage is to rely on communications satellite and cable technology, realize the remote computer online network, and ultimately achieve a global network. Cable TV, also known as "Community Antenna Television", receives a long distance radio or satellite through high-power wireless radio, transmit technology information, television signals and transmit information to users through underground cable. With the wide application of 
information technology, the essence of information technology development is technological development. Modern information technology is widely applied to the library and information institutions, transforming the quantitative change of library and information institution standard into technical content.

Library and information institution service is the main force. However, with the rise of new information services, especially rapid development of the Internet after the 1990s, its position is seriously affected, causing difficulties in information resource construction, severe shortage of funds and information service space. Faced with the enormous challenges of survival and development, how to successfully achieve the transition to the modern information service industry and look a place have become emergent library and information issues for modern information service industry to be solved. In the historical process of modernization, the developments of information technology, market economy, and new information services are three fundamental forces promoting the reform of library and information institutions. Information library and information service is the core of the work, and information service modernization is the major route of library and information institutions. Based on extensive literature survey and comparative analysis, this paper summarizes the research results at home and abroad, learn from research results at home and abroad, discusses the basic options of library and information service as well as the modern information institution positioning in modern information service industry. The thesis is divided into four parts. Part One introduces the research background, basic ideas and research contents, purpose and significance. Part Two analyzes the basic concept, features and system structure of modern information services, and points out the modern valueadded core competitiveness information services. Part Three discusses the development, market and industry of modern information service industry; modern information service industry is the basic option of modernization of library and information institutions. Also, it summarizes the changes and evolution of management information service model, analyzes the library and information institution information service from the fitting relationship of modern information service, discusses its position in modern information service industry, highlights the value-added information service is the survival of library and information institutions, and proposes that new point of improvement in library and information service is digital library service model based on knowledge and services.

\section{CONCLUSIONS}

In conclusion, the wide application of information technology not only brings major change to library and information institutions, but also changes the passive, single and traditional library and information service model, expand the service scope, improves service levels and quality, and speeds up the modernization of library and information service.

\section{REFERENCES}

[1] Huating Li. Impacts of Modern Information Technology on Library and Information Service[J] Journal of Anyang Teachers College. 2001 (3) 81-82;

[2] Zhixin Jin. Innovative Practice of National Cultural Information Resources Sharing Project Service Means[J]. Library Development

[3] Junduan Liu. Second Information Technology Revolution and Library[J]; Tianjin Library Journal, 1997(3)18-25

[4] Cong Cong. Application of Information Technology in Book Management $[\mathrm{J}]$, China Science and Technology Expo, 2014(29)358

[5] Changzhi Fu. Thinking on Video Resources Construction of National Cultural Information Resources Sharing Project[J] Journal of the Library Science in Jiangxi, 2011(4):36-38

[6] Shuyin Liu. University Library Reader Works in Network Environment[J]. Library and Information Service, 2012(S2): 144-145.

[7] Jian Ouyang. Research on Library Information Resource Organization in Information Environment[J]. Library and Information Service, 2011, 55(19):116-117. 